\title{
GRAVIMETRIC ANALYSIS OF SELECTED TYPES OF BIOFUELS
}

\author{
Zuzana MIKULOVÁ, Ivan VITÁZEK*, Janko KLÚČIK \\ Slovak University of Agriculture in Nitra, Slovak Republic
}

\begin{abstract}
Biomass provides a great diversity of input materials and universal use, not only for heat generation but also electricity generation in modern incinerators. For the most efficient use of solid biofuels, it is necessary to know their physico-chemical properties. The work focuses on the gravimetric analysis of selected types of biofuels. This paper presents the results of measurements for moisture content, ash and combustibles in selected solid biofuels. Experiments represent a follow-up to measurements performed to date.
\end{abstract}

Keywords: biofuels, ash, moisture, combustibles, gravimetric method

All of us understand that energy is needed for our life, whether in the form of light, heat, fuel or other of its forms. The use of biomass for heat generation increases from year to year. In 2010, Slovakia used nearly 800,000 tonnes of biomass, but this year it should already be more than 2 million tonnes. According to the Regulatory Office for Network Industries of the Slovak Republic (ÚRSO), the consumption of biomass for heat generation has increased several times from 2010. Based on the law on promotion of electricity generated from renewable energy sources (RES), there was a synergistic effect in the production of heat, too. In heat generation from biomass, the rise in prices of petroleum products has a significant impact. Biomass is a basis of renewable energy sources, which nobody doubts now. It reaches up to $75 \%$ within renewable energy sources such as wind, water, sun, etc. Therefore, biomass is subjected to more and more research in terms of its use. Biomass is also one of the most versatile and most widely used renewable energy sources on the Earth. It also involves plant matter suitable for energy purposes as a renewable energy source.

Biofuel is a fuel from biomass. Biofuels are divided into solid, liquid and gaseous. The quality of solid biofuel as an energy source depends on moisture and ash content as well as on the composition of volatile combustible (Jandačka and Malcho, 2007). Gaseous or liquid forms of biomass can be used for motor fuels.

\section{Material and methods}

Biofuels from solid biomass are composed of various wood and plant materials, which go to laboratory tables mostly in the form of pellets or briquettes (e.g. patience pellets, pellets of bioethanol production, pellets from lucerne straw, from hay, triticale, from sawdust, briquettes from woodchips), but also in its original form (e.g. woodchips, grain, cereal straw with or without grain, flax, rapeseed straw, etc.). Some commodities may be in both forms, e.g. as straw as well as straw briquettes (Jandačka et al., 2011).

Known compacting technologies include briquetting, pelleting and compacting. The main difference among these technologies is in the size and shape of moulding and in the moulding process.

Laboratory tests are aimed at determining the two main parameters:

- performance characteristics relating directly to combustion of biomass (water content, ash content, hydrogen content, carbon content, determination of calorific value, etc.);

- factors affecting emissions and the environment (sulphur, nitrogen, chlorine, volatile matter, etc.).

Determination of physico-chemical properties of solid biofuels is performed in laboratories after taking a representative sample of solid biofuel. As with any other chemical analysis, very important is a correct sampling and correct sample preparation (Vitázek and Vitázková, 2012).

\section{Determination of physical properties}

\section{Determination of moisture content}

The water content of solid biofuels is one of the most important parameters affecting the fuel efficiency but also the quality of briquettes or pellets, and is one of the limit values for production of pellets from biomass. A higher water content of pressed material can result in the fact that pellets cannot be produced from it. For this reason, it is necessary to know the water content in solid biofuel (Jandačka et al., 2012).

\section{Determination of ash content}

Knowing the ash content allows determining the rest of biofuel after combustion. The content of elements can be determined after dissolving the ash. Ash represents a non-combustible solid component of material. In terms of chemical composition, it is the matter of oxides of silicon, aluminium, iron, calcium and other (Brestovič, 2006).

\section{Determination of volatile matter}

For combustor, it is important to know the content of volatile matter. A high proportion of combustibles may affect emissions and can make up $80 \%$ of the dry weight of fuel.

The measurements of moisture, ash and combustibles were carried out using a gravimetric furnace Nabertherm L9/11/SW/P330 (Fig. 1). 


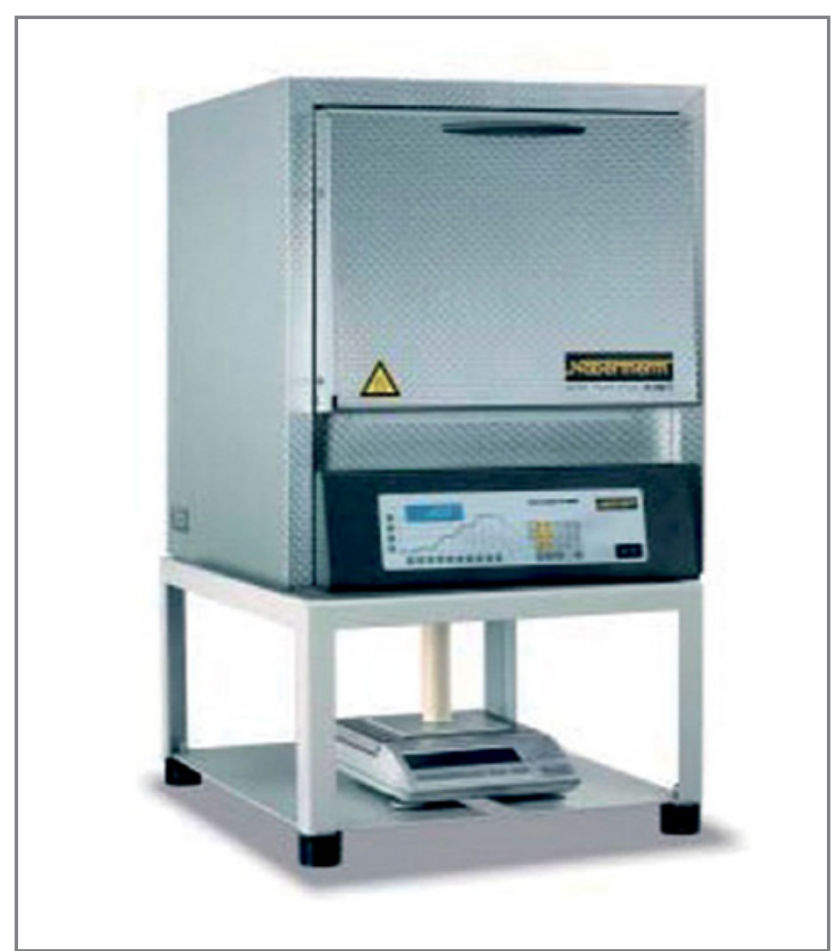

Figure 1 Gravimetric furnace Nabertherm L9/11/SW/P330

Moisture content is determined in accordance with the technical norm STN EN 14774-2. The sample is heated up to $105^{\circ} \mathrm{C}+2{ }^{\circ} \mathrm{C}$ and is dried up to a point when the difference in sample weight between two consecutive measurements carried out in a 60 minute interval does not exceed $0.2 \%$ of total sample weight loss obtained in previous weighing. The present paper introduces moisture content values for the analysed material.

The identification of proportion of volatile substances follows the norm STN EN15148. Ash content is determined in accordance with the norms STN EN 14775 and STN ISO 1171. The analysed sample is combusted at a temperature of $815^{\circ} \mathrm{C}$ during the period of 60 minutes.

The sample of analysed solid biofuel in a ceramic bowl is inserted into the gravimetric furnace. Values representing chosen temperatures and their impact period are programmed by means of computer. Precise values are presented in Table 1.

Table 1 Parameters for gravimetric measurement procedure

\begin{tabular}{|l||c|c|}
\hline Time interval & Impact period in minute & Temperature in ${ }^{\circ} \mathbf{C}$ \\
\hline \hline $\mathbf{1}$ & 60 & $20-105$ \\
\hline $\mathbf{2}$ & 120 & 105 \\
\hline $\mathbf{3}$ & 60 & $105-500$ \\
\hline $\mathbf{4}$ & 60 & 500 \\
\hline $\mathbf{5}$ & 60 & $500-815$ \\
\hline $\mathbf{6}$ & 60 & 815 \\
\hline
\end{tabular}

Proportions of particular components are calculated according to the following relations:

\section{Moisture content $w$}

$$
w=\frac{m_{1}-m_{2}}{m_{1}} \times 100(\%)
$$

\section{Ash content}

in original sample condition $A^{\prime}$

$$
A^{\prime}=\frac{m_{3}}{m_{1}} \times 100(\%)
$$

in dry matter $p_{p s}$

$$
p_{p s}=\frac{m_{3}}{m_{2}} \times 100(\%)
$$

\section{Combustible content}

in original sample condition $h^{\prime}$

$$
h^{\prime}=\frac{m_{4}}{m_{1}} \times 100(\%)
$$

in dry matter phs

$$
p_{h s}=\frac{m_{4}}{m_{2}} \times 100(\%)
$$

where:

$m_{1}$ - original weight of sample, $\mathrm{g}$

$m_{2}$ - weight of dry matter, $g$

$m_{3}$ - weight of ash, $g$

$m_{4}$ - weight of combustible, $g$

\section{Results and discussion}

Temperatures above $100^{\circ} \mathrm{Clead}$ to removal of moisture - fuel drying. At temperatures above $150^{\circ} \mathrm{C}$, volatile matter begins to slightly release, and after exceeding temperatures from $260^{\circ} \mathrm{C}$ to $410^{\circ} \mathrm{C}$, the release of volatile matter is significantly accelerated. The solid portion of combustible begins to oxidise at a temperature of about $500{ }^{\circ} \mathrm{C}$. Temperature 815 ${ }^{\circ} \mathrm{C}$ leads to a perfect oxidation of solid residue (Jandačka et al., 2012).

The results of gravimetric measurements of analysed samples are shown in Table 2.

Experiments were focused on pellets made of different proportions of lignite and sawdust from hardwood (beech), or from rapeseed straw. For comparison, there are introduced the results of previous experiments with pellets from sunflower, Ukrainian peat briquettes and lignite briquettes. Interestingly, measurement values for grape marc, which is not used as biofuel, are also introduced.

As seen from the table, briquettes have the largest proportion of moisture. The lowest proportion of moisture is shown in pellet from sunflower, i.e. $4.940 \%$.

The contents of ash and combustibles are also shown in the table. Peat briquette from Ukraine has the largest proportion of ash, and lignite charcoal briquette has the smallest proportion of ash in its original condition. Furthermore, pellets and their share of ash in dry matter can be compared. Pellets from sunflower had the highest proportion, i.e. $7.496 \%$, and pellets composed of $10 \%$ lignite, 
Table 2 Results of gravimetric measurements of analysed samples

\begin{tabular}{|l||c|c|c|c|c|}
\hline \multicolumn{1}{|l||}{ Biofuels } & \multicolumn{5}{c|}{ Parameter } \\
\cline { 2 - 6 } & $w$ in $\%$ & $A^{\prime}$ in $\%$ & $h^{\prime}$ in $\%$ & $p_{p s}$ in $\%$ & $p_{h s}$ in $\%$ \\
\hline $\mathbf{1}$ & 6.560 & 3.273 & 90.150 & 3.510 & 96.499 \\
\hline $\mathbf{2}$ & 7.470 & 3.187 & 89.330 & 3.450 & 96.550 \\
\hline $\mathbf{4}$ & 7.289 & 5.538 & 87.173 & 5.974 & 94.026 \\
\hline $\mathbf{5}$ & 8.992 & 6.132 & 84.877 & 6.738 & 93.262 \\
\hline $\mathbf{6}$ & 4.940 & 7.129 & 87.930 & 7.496 & 92.504 \\
\hline $\mathbf{7}$ & 18.519 & 3.078 & 78.403 & 3.778 & 96.222 \\
\hline $\mathbf{8}$ & 14.593 & 18.099 & 67.308 & 21.188 & 78.812 \\
\hline
\end{tabular}

1 - pellets [15 \% lignite, $85 \%$ sawdust (hardwood)]; 2 - pellets [10 \% lignite, $90 \%$ sawdust (hardwood)]; 3 - pellets [35 \% lignite, $30 \%$ sawdust (hardwood), $35 \%$ rapeseed]; 4 - pellets [30 \% lignite, $40 \%$ sawdust (hardwood - beech), $30 \%$ rapeseed]; 5 - pellets (sunflower); 6 - briquette (lignite crushed); 7 - briquette (Ukrainian peat broken); 8 - grape marc

$90 \%$ sawdust (hardwood) had the lowest proportion of ash in dry matter (3.450\%). This means they had the highest proportion of combustible in dry matter, exactly $96.550 \%$.

Figure 2 shows the courses of weight losses in analysed samples of solid biofuels.

Based on the examined materials, the weight losses of which are shown in Figure 2, it is possible to state that the fastest decline in weight loss and thereby the fastest release of volatile matter is in the pellet composed of $10 \%$ lignite, $90 \%$ sawdust (hardwood) and the lowest decline in weight loss is in crushed briquette. The fastest and lowest weight loss decline is shown in Figure 3.

The fastest decline is shown in the samples with a high content of wood. Pellets containing less wood have a smoother decline. In crushed briquette and Ukrainian crushed peat briquette, these courses are gradual, which means they contain less volatile matter. These properties influence the course of combustion and thus a variety of requirements for combustor design, in particular the supply of combustion air.

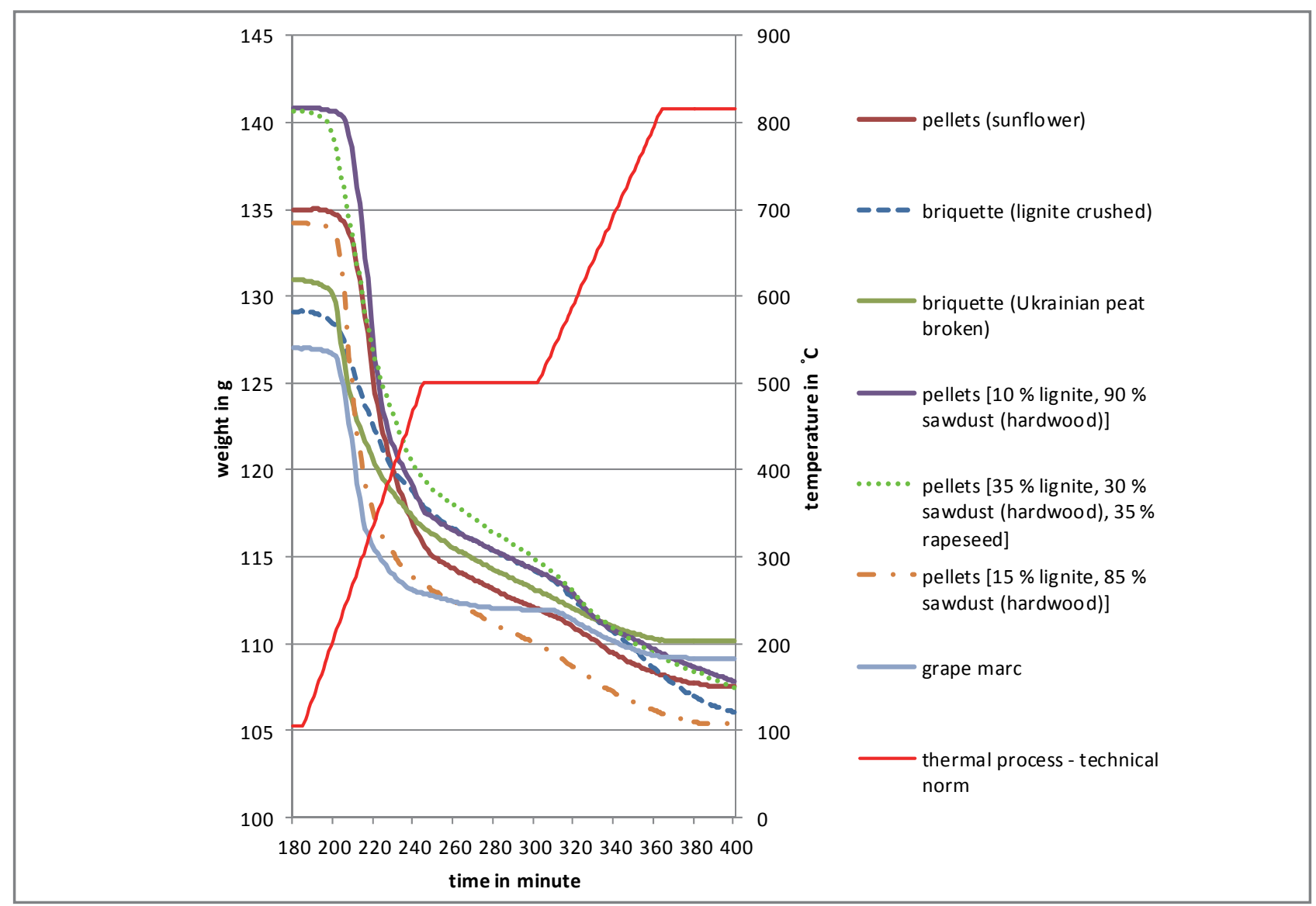




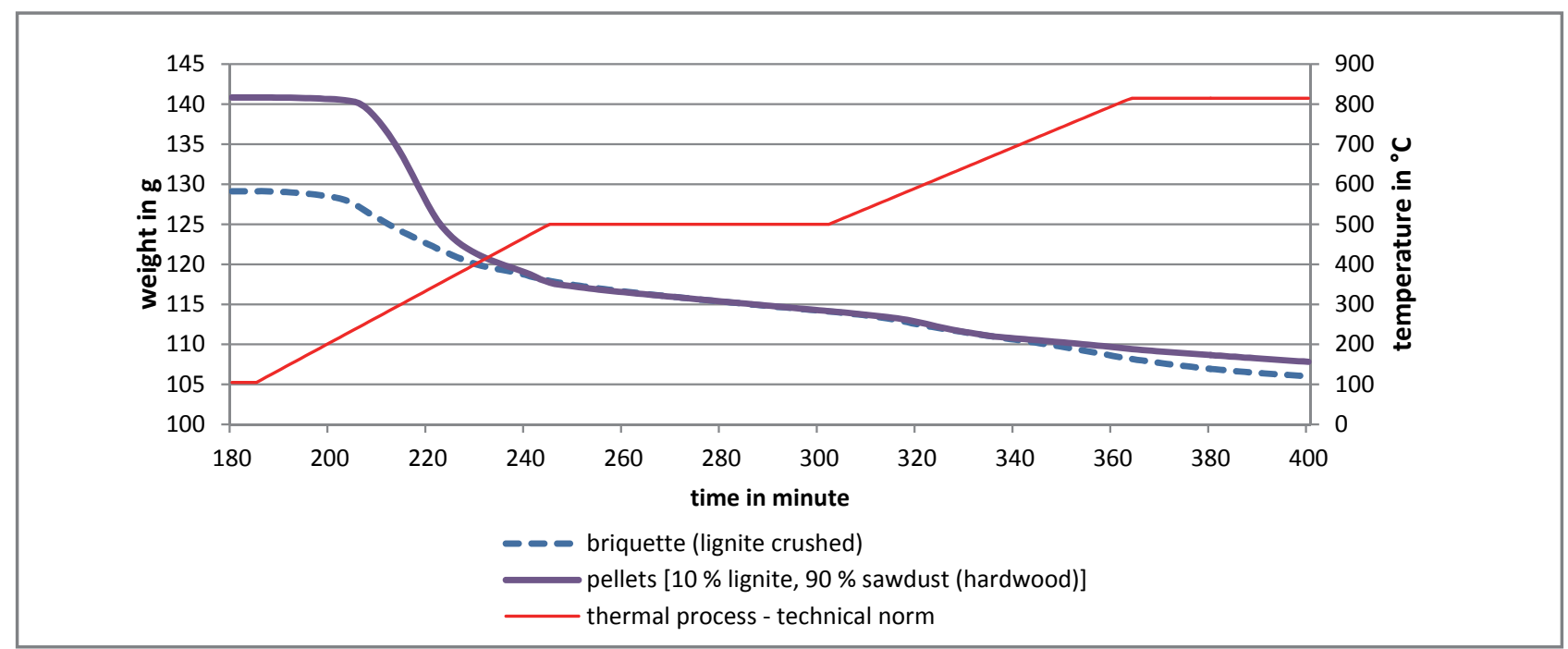

Figure 3 Fastest and slowest weight loss in analysed samples of solid biofuels

The paper of Vitázek and Vitázková (2012) shows the processed gravimetric measurements of selected types of biofuels, where it can be noticed that the softwood pellet has moisture content $9.025 \%$ and the pellet from softwood without bark $6.799 \%$ only. Regarding the ash content, the values are as follows: pellet from rapeseed waste plus cereals $7.988 \%$, corn stalks pellet $5.194 \%$, burnt corn pellet $4.708 \%$, corn spindle pellet $4.378 \%$, softwood pellet $1.029 \%$ and pellet softwood without bark $0.462 \%$.

Values for ash proportion in selected types of biomass presented in the paper of Rusňák and Šmidová (2010) and Opáth et al. (2010) are as follows: birch wood $1.2 \%$, aspen $2.6 \%$, wheat straw $5.7 \%$, corn straw $4.6 \%$, rapeseed straw $6.9 \%$, amaranth straw $13.5 \%$, pellets from grain dust $15.3 \%$, bio-sludge after separation from biogas plant $53.4 \%$.

\section{Conclusion}

In the context of biomass use for energy purposes, there are sought opportunities to use various materials and their combinations in the production of pellets, briquettes and for direct incineration.

Biofuels have different physical properties determining the method of their further processing. The present contribution documents the results of continuing research in the area of gravimetric examination of moisture, ash and combustibles at the Faculty of Engineering of the SUA in Nitra. The results obtained are graphically shown in Fig. 2. Briquette composed purely of lignite has ash content $3.778 \%$. After addition of sawdust, pellets composed of $10 \%$ lignite and $90 \%$ sawdust have ash content $3.450 \%$ only, but pellets composed of $15 \%$ lignite and $85 \%$ sawdust already have a slightly higher ash content, i.e. 3.510\%. When rapeseed is added to the composition of pellets, then pellets composed of $30 \%$ lignite, $40 \%$ sawdust and $30 \%$ rapeseed have ash content up to $6.738 \%$.

Said properties are important when selecting the combustor, its design and service.

\section{Acknowledgement}

This paper was prepared with the support of the project VEGA $1 / 0857 / 12$, Reduction of unfavourable impacts of agricultural and transport machinery on the environment' ${ }^{\prime}$ and of the project VEGA 1/0786/14,Effect of environmental aspects of machinery interactions on elimination of degradation processes in agrotechnologies of growing field crops'.

\section{References}

BRESTOVIČ, T. 2006. Stanovenie tepelného obsahu niektorých zložiek biomasy. In Novus scientia 2006 : 9. celoštátna konferencia doktorandov technických univerzít a vysokých škôl. Košice : TU, 2006. pp. 65-70.

JANDAČKA, J. - HOLUBČíK, M. - PAPUČÍK, Š. - NOSEK, R. 2012. Combustion of pellets from wheat straw. In Acta Montanistica Slovaca, vol. 17, 2012. no. 4, pp. 283-289.

JANDAČKA, J. - NOSEK, R. - HOLUBČÍK, M. - PAPUČÍK, Š. - ŽIDEK, L. - HARANT, R. - LENHART, P. 2011. Drevné pelety a aditíva. Žilina : Juraj Štefuň - GEORG, 2011. ISBN 978-80-89401-23-9.

JANDAČKA, J. - MALCHO, M. 2007. Biomasa ako zdroj energie. Žilina : GEORG, 2007. ISBN 978-80-969161-4-6.

OPÁTH, R. et.al. 2010. Horlavina a popol v sušine vybraných biopalív. In Agrobioenergia, vol. 5, 2010. no. 2, pp. 6-8.

RUSŇÁK, P. - ŠMIDOVÁ, E. 2010. Laboratórne analýzy biomasy a biopalív v Technickom a skúšobnom ústave pôdohospodárskom. In Agrobioenergia, vol. 5, 2010. no. 3, pp. 23-25.

STN EN 14774-2: 2010. Tuhé biopalivá. Stanovenie obsahu vlhkosti. Metóda sušením v sušiarni. Čast' 2: celková vlhkost'. Zjednodušená metóda. 2010.

STN EN 14775: 2010. Tuhé biopalivá. Stanovenie obsahu popola.

STN EN 15148: 2010. Tuhé biopalivá. Stanovenie obsahu prchavých látok.

STN ISO 1171: 2003. Tuhé biopalivá. Stanovenie obsahu popola.

VITÁZEK, I. - VITÁZKOVÁ, B. 2012. Selected physical properties of solid biofuels. In PTEP - Journal on Processing and Energy in Agriculture, vol. 16, 2012. no. 4, pp. 165-168.

\section{Contact address:}

Ivan Vitázek, Slovak University of Agriculture in Nitra, Faculty of Engineering, Department of Transport and Handling, Tr. Andreja Hlinku 2, 94976 Nitra, Slovak Republic, e-mail: ivan. vitazek@uniag.sk 